\title{
Foraging plasticity of Atta cephalotes (Hymenoptera: Formicidae) in response to temperature differences between forest and pasture
}

\author{
Santiago Bustamante ${ }^{1} \&$ Angela Amarillo-Suárez ${ }^{2}$ \\ 1. Universidad Tecnológica de Pereira, Carrera 27 \#10-02 Barrio Alamos - Risaralda - Colombia; \\ santiago.bustamante@utp.edu.co \\ 2. Pontificia Universidad Javeriana, Departamento de Ecología y Territorio Bogotá D.C. Carrera 7 No. 40 - 62; \\ aamarillo@javeriana.edu.co
}

Received 22-X-2018. C Corrected 21-V-2019. Accepted 29-VII-2019.

\begin{abstract}
Introduction: Changes in microclimatic conditions due to land cover transformations influence variations in population life histories and the developmental patterns of organisms. These variations can have a genetic basis, an environmental basis, or both. Objective: To determine the differences between habitats in the foraging activity of Atta cephalotes in response to changes in temperature and the extent to which any such differences are due to phenotypic plasticity, genetic variability, or both. Methods: We performed foraging experiments; each colony ( 4 colonies sourced from pasture and 3 colonies sourced from forest) underwent eight temperature treatments from 10 to $45^{\circ} \mathrm{C}\left( \pm 1{ }^{\circ} \mathrm{C}\right)$ at $5{ }^{\circ} \mathrm{C}$ intervals, using common garden and reciprocal transplant experiments. Results: We found high plasticity in the foraging activity of Atta cephalotes in response to temperature, with the foraging activity gradually increasing from 15 to $35^{\circ} \mathrm{C}$. Additionally, we found no significant differences in the foraging activity between the colonies sourced from the pasture and forest. Conclusions: The foraging activity of $A$. cephalotes was directly proportional to temperature, with ants exhibiting thermophilic behaviors and high plasticity, and there were no differences in the foraging activity between colonies sourced from both habitats.
\end{abstract}

Key words: leaf-cutting ants; plasticity; temperature; microclimatic changes; tropical dry forest.

Bustamante, S., \& Amarillo-Suárez, A. (2019). Foraging plasticity of Atta cephalotes (Hymenoptera: Formicidae) in response to temperature differences between forest and pasture. Revista de Biología Tropical, 67(4), 963-974.

Anthropogenic transformations of landscapes due to agriculture and cattle ranching cause ecological differences between nearby areas as climatic changes and reduction in diversity. These differences generate differential selection pressures that can cause adaptive changes in populations over very short time scales, even less than a hundred years. This process, known as contemporary evolution (Colautti \& Lau, 2015; Stockwell, Hendry, \& Kinnison, 2003), has been extensively documented in recent literature and occurs in a variety of organisms (Bone \& Farres, 2001; Reznick \& Ghalambor, 2001; Reznick, Shaw, Rodd, \&
Shaw, 1997; Stockwell \& Weeks, 1999) such as fish, (Heath, Heath, Bryden, Johnson, \& Fox, 2003), reptiles (Phillips \& Shine, 2006), mammals (Pigeon, Festa-Bianchet, Coltman, \& Pelletier, 2016), plants (Burger \& Ellstrand, 2014; Colautti \& Barrett, 2013), and insects (Singer, 2000), including Coleoptera (Szucs, Schaffner, Price, \& Schwarzländer, 2012) Phasmatodea (Farkas, Mononen, Comeault, Hanski, \& Nosil, 2013), Hymenoptera (White, 2011), and Lepidoptera (White, 2011).

Human activities such as agriculture and cattle grazing strongly modify the structure and composition of plant communities and 
the physical structure of ecosystems (Nunes de Oliveira, Abílio de Carvalho, Trancoso Gomes, Fontes Guimarães, \& Concepta Margaret, 2017), altering nutrient cycles and their prevailing microclimatic regimes (Wilson, Liang, Wilson, \& Akiwumi, 2018). Changes in microclimatic conditions influence variations in population life histories and the developmental patterns of organisms (Kinnison, Hendry, \& Stockwell, 2007; Stockwell et al., 2003). These variations can have a genetic basis, an environmental basis, or both (Kinnison et al., 2007; Stockwell et al., 2003). If the variation in a trait has a genetic component and responds to a particular microclimatic pattern, it results in adaptive changes (Hoffmann \& Sgró, 2011). There is evidence from many plants and animals suggesting the existence of heritable variations in all types of adaptive traits (Pigliucci, 2001), including physiological (Houle, 1991; Shirangi, Dufour, Williams, \& Carroll, 2009), morphological (Arnold, 1981; Grant \& Grant, 2006), life history (Mousseau \& Fox, 1998), developmental and behavioral traits (Avise, 2008; James \& Partridge, 1995).

To understand trait evolution, it is necessary to consider the patterns of environmental heterogeneity and the ways in which natural selection affects the phenotypic traits of organisms (Mousseau, Sinervo, \& Endler, 2000). Because of environmental heterogeneity, local adaptations may arise from the differential effects of natural selection on a deme due to differences in phenotypic traits between organisms. In this case, organisms are assumed to exhibit higher fitness under local environmental conditions than under the conditions of other habitats (Kawecki \& Ebert, 2004; Mousseau et al., 2000). Differences in phenotype result from differences in genotype, changes in environmental factors over the same genotype, or the interaction between genotype and environment.

Phenotypic plasticity has been defined as the property of a single genotype to express different phenotypes across different environmental conditions (Richards, Bossdorf, Muth, Gurevitch, \& Pigliucci, 2006). This plasticity can be expressed by the reaction norm, which is a function of the genotype expression under specific environmental conditions. In a reaction norm, the $\mathrm{x}$-axis represents the environmental gradient, and the $y$-axis represents the phenotype (Pigliucci, 2001). If there is plasticity, the reaction norm will have a slope different than zero. If there is no variation in plasticity in the population, all reaction norms should be parallel, whereas in the absence of genetic variation in the trait itself, there should be a single reaction norm (Mousseau et al., 2000). However, if there is variation in phenotypic plasticity, the population is represented by a set of reaction norms with different slopes, which indicate an interaction between genotype and environment. The graphical model of the genotype due to environmental interactions is a more formal statistical interaction (Mousseau et al., 2000). Thus, phenotypic plasticity offers a theoretical framework to study the influence of genes and the environment on the genotype (Mousseau et al., 2000). A trait is considered plastic if the test (e.g., an ANOVA) for the effect of an environmental factor on that trait is statistically significant (Pigliucci, 2001; Richards et al., 2006).

Leaf-cutting ants (LCAs) from the genera Atta and Acromyrmex (Hymenoptera: Formicidae: Attini) are an ideal group for studying the adaptation of local populations to environmental variations such as microclimatic change. These ants evolve in dry or seasonally dry habitats and disperse to a large variety of habitats (Branstetter et al., 2017). They are considered central-place foragers, which allow the monitoring of behaviors for long periods of time under field conditions (Burd \& Howard, 2005). These ants are very common and widely distributed in the lowlands of Colombia (Fernández, Cartro-Huertas, \& Serna, 2015). Atta cephalotes can develop successfully in different habitats and microclimatic conditions (Montoya-Lerma, Giraldo-Echeverri, Armbrecht, Farji-Brener, \& Calle, 2012). A. cephalotes is a common species in the Cauca Valley, (Chacon, Osorio-García, Achury, \& Bermúdez, 2012; Montoya-Lerma et al., 2012), a region that was originally forested but has undergone deforestation since 1550 (CVC, 1990). This 
process has been driven by the introduction of cattle grazing and sugar cane plantations. As a consequence, the landscape includes only a few remaining forest fragments, which corresponds to less than $2 \%$ of the original forest area (Arcila Cardona, Chacon, \& Valderrama, 2012) immersed in a matrix of pastures dedicated to cattle grazing (CVC, 1990). The microclimatic conditions of the foraging trails of A. cephalotes differ greatly between these two habitats (Bustamante, 2017). For example, the mean soil temperature at noon can be $5{ }^{\circ} \mathrm{C}$ higher in the pasture than in the forest, and the maximum soil temperature can be $11{ }^{\circ} \mathrm{C}$ higher in the pasture than in the forest. Additionally, the relative humidity (RH) in the pasture is $15 \%$ lower than that in the forest (Bustamante, 2017). Despite these strong differences in microclimatic conditions, A. cephalotes is a common species and can be found in both the forest and the pasture (Chacon et al., 2012). Such These differences in temperature can act as a source of disruptive selection (Bennett, Dao, \& Lenski, 1990) and generate populations that are locally adapted to the climatic regimes of forests and pastures (Kisdi, 2002).

The ability of $A$. cephalotes to use and adapt to different environments might be due to the following traits: (1) high genetic variability between populations, with each population locally adapted to the conditions of its habitat; (2) plasticity of foraging activity, which allows the expression of different phenotypes in response to variations in local environmental conditions; or (3) both high genetic variability and high plasticity (Futuyma, 2001). In this study, we used common garden experiments to determine whether there are differences between the habitats in the foraging activity of $A$. cephalotes in response to changes in temperature and the extent to which any of these differences are due to phenotypic plasticity, genetic variability, or both. Our hypothesis is that differences in the foraging activity observed between populations sourced from forests and pastures in response to changes in temperature are due to plasticity in foraging behavior.

\section{MATERIALS AND METHODS}

This study was conducted in the area of the Cauca River Valley, which is a $15000 \mathrm{~km}^{2}$ inter-Andean valley with a gradient ranging from 900 to 1000 m.a.s.l. This area has been highly transformed by agriculture and cattle grazing since 1550 (Etter \& van Wyngaarden, 2000). Within the valley, there are only a few small forest remnants (covering less than $2 \%$ of the original area), with an average area of 12 ha (GEMA, 1998). The average annual rainfall is $1700 \mathrm{~mm} /$ year with the majority occurring in wet seasons (March-May and September-November). There are two wet and two dry seasons in the region throughout a year (Ramírez, Chacon, Armbrecht, \& Calle, 2002). The annual average temperature is $24{ }^{\circ} \mathrm{C}$. According to the Holdridge classification, the area corresponds to a tropical dry forest (TDF) (Ramírez et al., 2002).

Two sites in the Cauca Valley were selected for ant collection on the Alejandría farm (Fig. 1), near the city of Pereira. One site, hereafter referred to as "the forest" $\left(4^{\circ} 51^{\prime} 15^{\prime}\right.$ " N \& $\left.75^{\circ} 52^{\prime} 48^{\prime \prime} \mathrm{W}\right)$, contains the original vegetation of a TDF (GEMA, 1998; Holdridge, Grenke, Hatheway, Liang, \& Tosi, 1971). The forest has an area of approximately 13 ha, is characterized by low anthropic intervention and a $30 \mathrm{~m}$ high canopy and has almost 300 plant species (Silverstone-Sopkin, personal communication). The other site, hereafter referred to as "the pas-

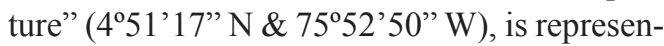
tative of the matrix surrounding the forest. It is composed of introduced pastures established in the first decade of the $20^{\text {th }}$ century for grazing Zebu cattle (Bos taurus indicus) at an average density of 1.5 head per hectare. The pastures are divided by live fences of matarratón (Gliricidia sepium), mestizo (Cupania latifolia), old fustic (Maclura tinctoria), and tachuelo (Xantansillum sp.). The studied TDF has a buffering effect on the temperature of the LCA foraging trail, resulting in differences in average temperature between the two habitats during the hottest hours of the day. These differences are mostly due to higher maxima in open sites. The 

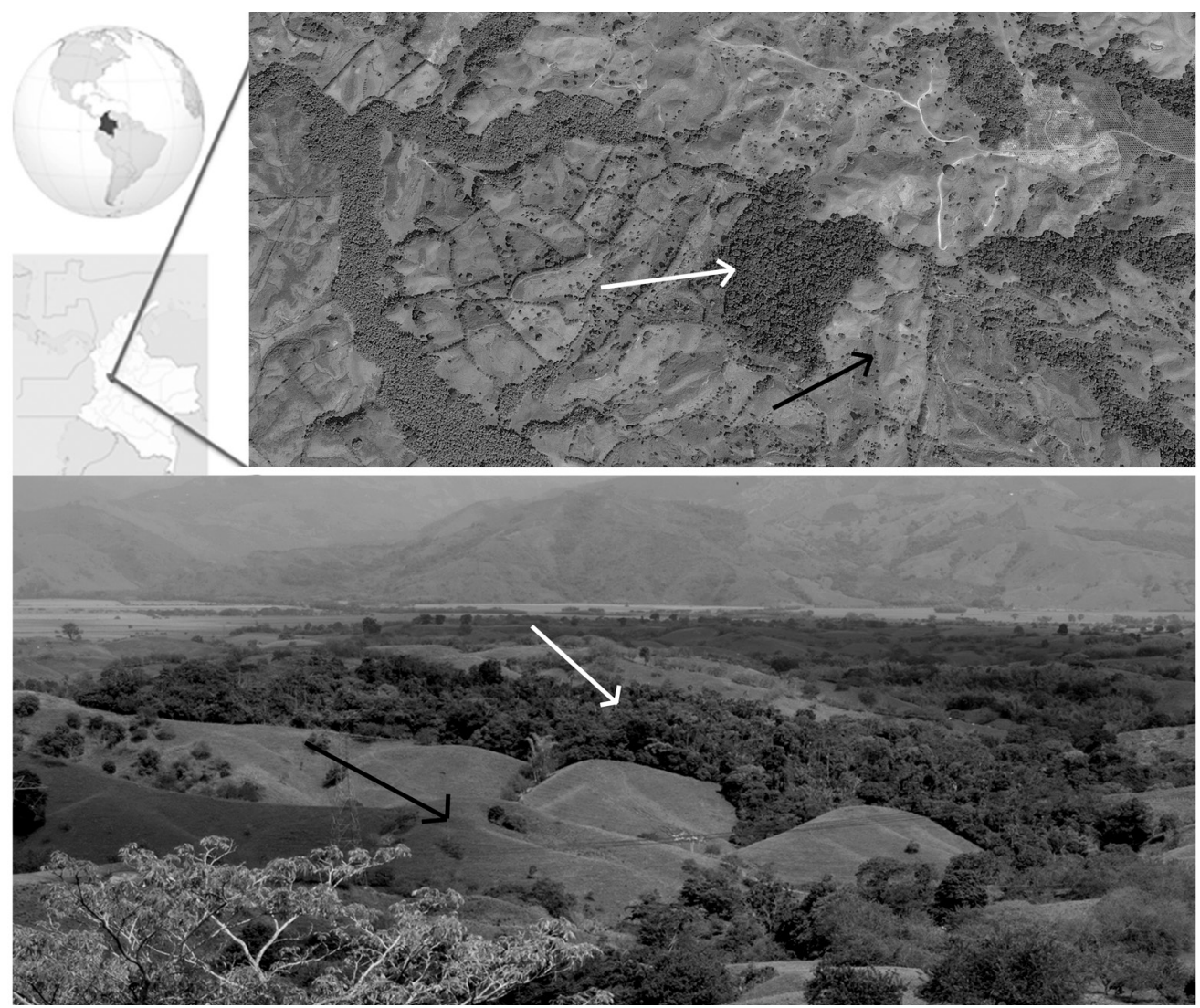

Fig. 1. Location of the study site. The white arrow shows the forest, and the black one shows the pastures (top right image modified from source: (CGoogle earth 2019).

average air temperature at noon is $24.5^{\circ} \mathrm{C}$ in the forest compared with $31.0^{\circ} \mathrm{C}$ in the pasture. These data were measured using 6 data loggers located $5 \mathrm{~cm}$ above the soil surface on the main foraging trail near the entrance hole of 6 different colonies that recorded measurements at hourly intervals from May $18^{\text {th }}$ to December $12^{\text {th }}$ of 2013 (Bustamante, 2017).

Four random small $A$. cephalotes colonies, each including the ants, queen and symbiotic fungus were collected from the pasture, and three subcolonies from different nests, each including the ants and symbiotic fungus but without the queen, were collected from the forest. We collected subcolonies in the forest because it was not possible to locate small colonies in the forest. The colonies and subcolonies (hereafter, colonies) were collected together with a fungus garden volume of approximately 2 L in January 2015; the minimal distance between colonies was $100 \mathrm{~m}$. The colonies were maintained in the laboratory of Evolutionary Ecology and Conservation at Pontificia Universidad Javeriana-Bogotá at ca. $24{ }^{\circ} \mathrm{C}$ under a light-dark (LD) cycle of 12:12 h. We maintained the temperature of the garden box at $24{ }^{\circ} \mathrm{C}$ during the experiments because the fungal symbiont does not tolerate extreme temperatures (Powell \& Stradling, 1986), unlike the individual ants (Tizón, Wulff, \& Peláez, 2014). The aim of our study was to investigate how environmental temperature affects ant foraging. The colonies were fed black elder Sambucus nigra (Adoxaceae) leaves (Adoxaceae) for a period of 15 days, providing the necessary amount of time for the colonies to rearrange 
their nests and establish normal development. To minimize any colony differences in the number of eggs and larvae due to queen oviposition behaviors, the experiments were performed with the colonies at a time no more than two months after their collection from the field. We expected no differences between the colonies and subcolonies in foraging activity, as has been found in numerous studies on LCA foraging ecology and food plant selection based on the subcolony approach, e.g., Saverschek, Herz, Wagner, and Roces (2010) and Thiele, Kost, Roces, and Wirth (2014).

To determine whether there are differences between the habitats in the foraging activity of A. cephalotes in response to changes in temperature and the extent to which any such differences are due to phenotypic plasticity, genetic variability, or both, we performed common garden and reciprocal transplant experiments (Ballentine \& Greenberg, 2010; Mousseau et al., 2000). For this, it was necessary to modify the temperature of the foraging trail without modifying the temperature of the garden box. Each nest was connected to a food box via a $2.54 \mathrm{~cm}$ diameter, $50 \mathrm{~cm}$ long tube. The tube and the food box were submerged in a water container (Fig. 2). We ensured that the tube and food box were hermetically sealed. The temperature of the foraging trail and the food box was controlled using a water bath. To homogenize the water temperature in the food box, we used a small water pump to circulate the water surrounding the foraging tube and food box. The water was heated with an immersion heater. Once the desired temperature was reached in the food box, we recorded the temperature every minute to ensure that it remained constant throughout each experiment. We placed 20 fresh black elder leaves in the food box at the beginning of each experiment.

To perform the foraging experiments, the colonies ( 4 from the pasture and 3 from the forest) underwent eight temperature treatments ranging from 10 to $45{ }^{\circ} \mathrm{C}\left( \pm 1{ }^{\circ} \mathrm{C}\right)$ at $5{ }^{\circ} \mathrm{C}$ intervals. Once the connection between the colony and the food box was established by the foraging trail (in the tube) and the desired temperature was fixed, we allowed foraging to proceed for one hour to ensure a continuous foraging column of ants. The ants were counted at the observed colony's foraging peak and one hour after the feeding time, and all the records were completed at $14 \mathrm{~h}$. The response variable was the number of laden ants returning to the colony over a five-minute period and was recorded using a hand counter.

We used linear regression to determine the relationship between foraging activity and temperature. Additionally, we evaluated differences in the foraging activity between colonies from the pasture and the forest by performing repeated measures ANOVA (type III sum of squares) with temperature and habitat as fixed factors and "nest" as the subject. Repeated measure analysis was performed because each nest was exposed to eight different temperatures. When significant results were obtained, we performed specific post hoc comparisons between pairs of temperatures using LSD post hoc tests. All calculations were performed with R software (R Core Team, 2015).

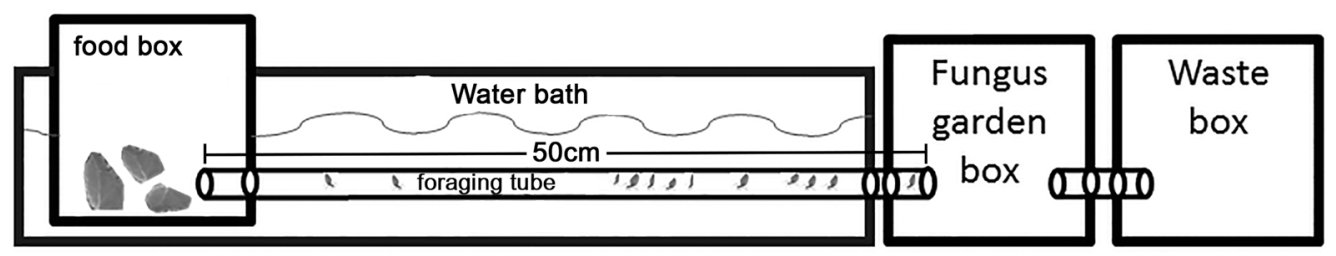

Fig. 2. The experimental setup of the experiment comprises three boxes connected by tubes. Each box has a volume of 2 L. The colony is housed in the fungus garden box, and the ants travel through the foraging tube to reach the leaves in the food box. The temperature of the water bath is controlled to regulate the temperature in the foraging tube and food box. 


\section{RESULTS}

Regardless of habitat origin, there were observed differences in the foraging activity of ants in response to temperature $\left(F_{(7,7)}\right.$ $=22.73, \mathrm{P}<0.001$; Fig. 3). We found high plasticity in the foraging activity in response to temperature, with foraging activity gradually increasing from 15 to $35^{\circ} \mathrm{C}$. The increase in the foraging activity for ants sourced from both habitats was similar. Ants from the forest showed an increase in foraging activity from 7.3 to 17 laden ants, while in ants from the pastures; the increase was from 7.25 to 21 laden ants (Table 1). In this range, $A$. cephalotes displayed thermophilic behaviors, with activities being more than twice as high at $35^{\circ} \mathrm{C}$ than at $15{ }^{\circ} \mathrm{C}$ (Fig. 3). The observed foraging activity was a linear function of temperature within the range from 15 to $35^{\circ} \mathrm{C}$, as defined by the following regression lines: (1) the forest nests, Activity $=0.46$ Temperature $+0.76, \mathrm{R}^{2}=0.53$, $\mathrm{P}<0.0018, \mathrm{~N}=15$, and (2) the pasture nests, Activity $=0.66$ Temperature $-2.7, \mathrm{R}^{2}=0.43, \mathrm{P}$ $<0.0014, \mathrm{~N}=20$. Despite the high plasticity in response to changing temperature, we found no significant differences in foraging activity between the colonies from the pasture and the forest $\left(F_{(1,7)}=0.75, \mathrm{P}=0.42\right.$; Fig. 3$)$ and no interaction between foraging activity and the temperature of the foraging trail $\left(F_{(7,35)}=0.27\right.$, $\mathrm{P}=0.96$; Fig. 3). These results indicated that the forest and pasture populations responded in a similar way to temperature and showed an absence of genetic differences in the plasticity of the foraging activity between the colonies from different habitats.

TABLE 1

Average number of ants carrying fragments in response to temperature from the forest and the pasture

\begin{tabular}{ccc}
$\begin{array}{c}\text { Temperature } \\
\left({ }^{\circ} \mathrm{C}\right)\end{array}$ & $\begin{array}{c}\text { Ants from the forest } \\
(\text { mean } \pm \mathrm{SE})\end{array}$ & $\begin{array}{c}\text { Ants from the pasture } \\
(\text { mean } \pm \mathrm{SE})\end{array}$ \\
10 & $0 \pm 0$ & $0 \pm 0$ \\
15 & $7.33 \pm 1.2$ & $7.25 \pm 3.35$ \\
20 & $10.67 \pm 2.4$ & $11.75 \pm 1.31$ \\
25 & $12 \pm 2.31$ & $11.5 \pm 3.23$ \\
30 & $14.33 \pm 2.6$ & $17.25 \pm 3.84$ \\
35 & $17 \pm 1.73$ & $21 \pm 2.48$ \\
40 & $1 \pm 0.58$ & $2.75 \pm 1.7$ \\
45 & $0 \pm 0$ & $0 \pm 0$ \\
\hline
\end{tabular}

\section{DISCUSSION}

A. cephalotes showed high plasticity in foraging activity in response to temperature in both the forest and the pasture colonies (Fig. 3). As a thermophilic behavior, higher

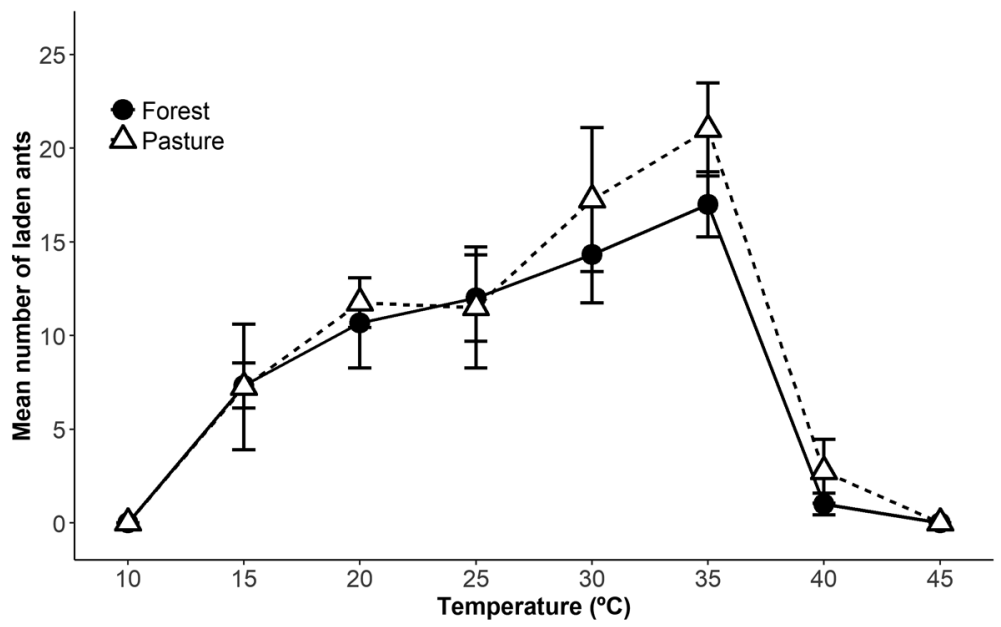

Fig. 3. Effect of temperature on foraging activity of Atta cephalotes from nests corresponding to the forest and pasture habitats in Cauca Valley, Colombia. Means correspond to three colonies from the forest and four colonies from the pasture. Error bars represent $\pm 1 \mathrm{SE}$ of the mean; for some points, the bars are smaller than the symbols. 
foraging activity with increasing temperature was observed from 10 to $35^{\circ} \mathrm{C}$, the maximum temperature to which the ants were observed foraging; foraging activity declined drastically at higher than $35^{\circ} \mathrm{C}$. Additionally, the forest and the pasture colonies responded similarly to temperature changes, indicating a lack of genetic differences between their plasticity.

The plasticity in foraging activity, allowing foraging under different temperatures, might be the result of adaptations of $A$. cephalotes to environments in which temperature changes drastically within a day, such as fragmented forests (Opdam \& Wascher, 2004). The $A$. cephalotes plasticity that we observed might increase the tolerance of ants to changes in temperature selection regimes by allowing them to rapidly adjust their foraging to accommodate new thermal conditions. Similarly, this plasticity might allow ants to rapidly acclimatize to changes in land cover, thereby facilitating their expansion into new and harsh environments and increasing their probability of survival (Snell-Rood, 2013). This expansion might include highly modified landscapes such as pastures, sugar cane plantations, and urban settings, as has been observed throughout the neotropical region (Leal, Wirth, \& Tabarelli, 2014; Montoya-Lerma et al., 2012). Our findings show that natural selection will favor adaptive plasticity in $A$. cephalotes when populations are exposed to changing environments and that no single phenotype will show superior fitness through all environments (Ghalambor, McKay, Carroll, \& Reznick, 2007; Moran, 1992). If the phenotype expressed in each habitat, i.e., forest and pasture, is optimal, then plasticity would play a beneficial role in colonizing new habitats because the plastic response is in the same direction that is favored by directional selection of $A$. cephalotes (Ghalambor et al., 2007).

The selection for plasticity in a trait depends on the relationship between temporal heterogeneity and the response time of the trait (Alpert \& Simms, 2002). Under rapid environmental fluctuations, fitness is maximized by the production of generalist phenotypes or short-term phenotypic plasticity (Fierst,
2011). The high plasticity strategy is frequently observed in generalist species (Gimeno, Pas, Lemos-Filho, \& Valladares, 2009), and LCAs are not an exception; for this reason, LCAs are the most common insect in the neotropics and can be found in many land cover zones with different microclimatic conditions (MontoyaLerma et al., 2012).

The observed differences in temperature between the forest and the pasture might have affected many phenotypic characteristics that are unrelated to foraging activity and were not measured in this study. For example, high temperatures affect ant metabolic rates, resulting in high respiratory rates, locomotion speeds and other changes (Lighton, Bartholomew, \& Feener Jr., 1986). Moreover, the respiration $\mathrm{CO}_{2}$ production of $A$. cephalotes ants increases 7-fold within a temperature gradient from 18 to $42{ }^{\circ} \mathrm{C}$ (Bustamante, 2017). Each phenotypic trait can respond in a different way to an environmental change; as a result, it is difficult to predict the evolutionary consequences of climatic change (Pulido \& Berthold, 2004), as for example, the responses of ants to changes in temperature. However, quantifying phenotypic plasticity is important for understanding the responses of species to environmental changes and modeling the effects of global climatic changes on species distributions (Valladares, Sanchez-Gomez, \& Zavala, 2006). At the community level, the ants have shown thermophilic behaviors, as warming consistently increased the occupancy of the nest and decreased extinction and nest abandonment (Diamond et al., 2016)

One possible explanation why we did not find differences between populations sourced from the forest and pastures is that other sources of selection might counteract the effect of temperature on the foraging activity of $A$. cephalotes. One potential source of selection on foraging activity is phorid flies. Bragança, Tonhasca and Della Lucia (1998) found that A. sexdens forages mostly at night in the field, but when colonies undergo periods of diurnal foraging, ants are subject to parasitism from several species of phorid flies. Bragança et 
al. (1998) argue that phorids may have a significant impact on their hosts by altering their foraging behavior regardless of the numerical values of parasitism (Bragança et al., 1998). Additionally, the fragile mutualistic relationship between LCAs and their symbiont fungus might impose strong selection on ant colonies because the fungus is very susceptible to microclimatic changes (Shik et al., 2014). Moreover, ants of different species or colonies that forage at the same site compete to forage at times at which the ambient temperature is less hostile, with the dominant species foraging within the most suitable temperature ranges (Cerdá, Retana, \& Cros, 1998).

Although we observed plasticity in the response of $A$. cephalotes to temperature, we found no evidence of genetic variation in plasticity between the forest and the pasture colonies based on the common garden experiments. They responded similarly to temperature. This result might be due to continuous gene flow between the forest and the pasture colonies, which would prevent genetic differentiation. This is a plausible explanation because mating apparently occurs high in the air, and many colonies conduct their nuptial flights during the same period of the day; therefore, the probability of outbreeding is high (Moser, 1967). Additionally, the ants can change the temperature at which they are exposed by changing the place of the foraging trail; thus, the site choice plays an important role modifying the ant ambient temperatures (Baudier, D'Amelio, Sulger, O'Donnell, \& O'Connor, 2018).

Development may require more stringent thermoregulation of pupae. Our data also suggest that site choice played an important role in bivouac cooling under high ambient temperatures at low elevations.

The nuptial flights of all of the Atta colonies belonging to the same species and living in the same region appear to be highly synchronized (Wirth, Herz, Ryel, Beyschlag, \& Hölldobler, 2003). Additionally, one A. colombica queen is inseminated by one to five males (Fjerdingstad \& Boomsma, 1998). Thus, it is feasible that an $A$. cephalotes queen from one habitat might mate with males from her own habitat and those from adjacent habitats, preventing adaptation to local conditions (Mayr, 1942; Slatkin, 1987).

Another hypothesis for the lack of observed genetic differences in foraging activity between the forest and the pasture colonies involves sperm storage. The queen stores male sperm in the spermatheca and fertilizes eggs with these sperm for up to nine years (Meyer, Leal, \& Wirth, 2009), causing genetic changes to occur more slowly than in populations in which the young males can breed with both young and old females and contribute different proportions of allele frequency. Under such a scenario, the nearly one hundred years that have elapsed since the transformation of land cover in the study region might be insufficient to generate genetic differences between the pasture and forest colonies.

To conclude, the foraging activity of $A$. cephalotes was directly proportional to temperature, with ants exhibiting thermophilic behaviors and high plasticity. Given that changes in temperature are one of the best indicators of climate disruption, driving changes in correlated environmental conditions, such as relative humidity and solar radiation, the developmental plasticity of $A$. cephalotes might allow it to tolerate climatic global changes and colonize novel habitats. Thus, the high plasticity of $A$. cephalotes foraging behavior in response to temperature might partially explain why this species has become a winner species in ecosystems such as pastures, crops and urban settings.

Ethical statement: authors declare that they all agree with this publication and made significant contributions; that there is no conflict of interest of any kind; and that we followed all pertinent ethical and legal procedures and requirements. All financial sources are fully and clearly stated in the acknowledgements section. A signed document has been filed in the journal archives. 


\section{ACKNOWLEDGMENTS}

Our research was supported by a doctoral scholarship from the program of Doctorados en Colombia, convocatoria No. 511 de 2010 - créditos beca Francisco José: de Caldas. The Facultad de Estudios Ambientales y Rurales, Pontificia Universidad Javeriana, Bogotá and Laboratory of Evolutionary Ecology and Conservation provided logistic and equipment support through Project ID 6530. We thank Felipe Vaughan for correcting the grammar and style of the manuscript and are grateful to the five anonymous reviewers for critically reading this paper.

\section{RESUMEN}

Plasticidad de "forrajeo" de Atta cephalotes (Hymenoptera:Formicidae) en respuesta a las diferencias de temperatura entre bosque y pastura. Introducción: los cambios en las condiciones microclimáticas debidos a la transformación de las coberturas vegetales genera variaciones en las historias de vida de las poblaciones y en los patrones de desarrollo de los organismos. Estas variaciones pueden tener bases genéticas, ambientales o ser el resultado de una interacción entre ambas. Objetivo: determinar las diferencias en la actividad de "forrajeo" de Atta cephalotes en respuesta a los cambios de temperatura en dos hábitats adyacentes y hasta qué grado estas diferencias son dadas por la plasticidad fenotípica, la variabilidad genética o la interacción de las dos. Métodología: se realizaron experimentos de "forrajeo"; cada colonia (4 colonias originarias de pasturas y 3 colonias originarias de bosque) se sometió a 8 tratamientos de temperatura de 10 a $45^{\circ} \mathrm{C}\left( \pm 1{ }^{\circ} \mathrm{C}\right)$ a intervalos de $5^{\circ} \mathrm{C}$ usando experimentos de crianza común y transferencia recíproca. Resultados: se observó una alta plasticidad en la actividad de "forrajeo" de Atta cephalotes en respuesta a la temperatura, con un incremento gradual del "forrajeo" desde los hasta los $35^{\circ} \mathrm{C}$. Adicionalmente no se encontraron diferencias significativas en la actividad de "forrajeo" entre las colonias originarias de la pastura y las del bosque. Conclusiones: la actividad de "forrajeo" de $A$. cephalotes, fue directamente proporcional a la temperatura, las hormigas mostraron un comportamiento termofílico y una alta plasticidad, y no hubo diferencias en la actividad de "forrajeo" entre colonias de los dos hábitats.

Palabras clave: hormigas arrieras; plasticidad; temperatura; alteraciones microclimáticas; bosque tropical seco.

\section{REFERENCES}

Alpert, P., \& Simms, E. L. (2002). The relative advantages of plasticity and fixity in different environments: When is it good for a plant to adjust? Evolutionary Ecology, 16(3), 285-297. DOI: 10.1023/A:1019684612767

Arcila Cardona, A. M., Chacon, P., \& Valderrama, C. (2012). Estado de fragmentación del bosque seco de la cuenca alta del río Cauca, Colombia. Biota Colombiana, 13(2), 86-101.

Arnold, S. J. (1981). Behavioral Variation in Natural Populations. I. Phenotypic, Genetic and Environmental Correlations Between Chemoreceptive Responses to Prey in the Garter Snake, Thamnophis elegans. Evolution, 35(3), 489-509.

Avise, J. C. (2008). The History, Purview, and Future of Conservation Genetics. In S. P. Carroll \& C. W. Fox (Eds.), Conservation biology: evolution in action (pp. 5-15). New York: Oxford University Press.

Ballentine, B., \& Greenberg, R. (2010). Common garden experiment reveals genetic control of phenotypic divergence between swamp sparrow subspecies that lack divergence in neutral genotypes. PLOS ONE, 5(4), 1-6. DOI: 10.1371/journal.pone.0010229

Baudier, K. M., D’Amelio, C. L., Sulger, E., O’Donnell, S., \& O'Connor, M. P. (2018). Plastic collective endothermy in a complex animal society (army ant bivouacs: Eciton burchellii parvispinum). Ecography, 42, 1-10. DOI: 10.1111/ecog.04064

Bennett, A. F., Dao, K. M., \& Lenski, R. E. (1990). Rapid evolution in response to high-temperature selection. Nature, 346(6279), 79-81. DOI: 10.1038/346079a0

Bone, E., \& Farres, A. (2001). Trends and rates of microevolution in plants. Genética, 112-113, 165-182.

Bragança, M. A., Tonhasca Jr., A., \& Della Lucia, T. M. (1998). Reduction in the foraging activity of the leaf-cutting ant Atta sexdens caused by the phorid Neodohrniphora sp. Entomologia Experimentalis et Applicata, 89(3), 305-311. DOI: 10.1046/j.1570-7458.1998.00413.x

Branstetter, M. G., Jesovnik, A., Sosa-Calvo, J., Lloyd, M. W., Faircloth, B. C., Brady, S. G., \& Schultz, T. R. (2017). Dry habitats were crucibles of domestication in the evolution of agriculture in ants. Proceedings of the Royal Society B: Biological Sciences, 284, 20170095. DOI: $10.1098 /$ rspb.2017.0095

Burd, M., \& Howard, J. J. (2005). Central-place foraging continues beyond the nest entrance: the underground performance of leaf-cutting ants. Animal Behaviour, 70, 737-744. DOI:10.1016/j.anbehav.2004.12.012 
Burger, J. C., \& Ellstrand, N. C. (2014). Rapid evolutionary divergence of an invasive weed from its crop ancestor and evidence for local diversification. Journal of Systematics and Evolution, 52(6), 750-764. DOI: $10.1111 /$ jse. 12111

Bustamante, S. (2017). Variation of foraging patterns of Atta cephalotes (Hymenoptera: Formicidae) in response to changes in microclimatic conditions caused by land cover changes (Tesis de doctorado). Pontificia Universidad Javeriana, Bogotá, Colombia.

Cerdá, X., Retana, J., \& Cros, S. (1998). Critical thermal limits in Mediterranean ant species: trade-off between mortality risk and foraging performance. Functional Ecology, 12(1), 45-55. DOI: 10.1046/j.1365-2435.1998.00160.x

Chacon, P., Osorio-García, A., Achury, R., \& Bermúdez, R. (2012). Hormigas (Hymenoptera: Formicidae) del Bosque seco Tropical (Bs-T) de la cuenca alta del río Cauca, Colombia. Biota Colombiana, 13(2), 165-181.

Colautti, R. I., \& Barrett, S. C. H. (2013). Rapid adaptation to climate facilitates range expansion of an invasive plant. Science, 342(6156), 364-366. DOI: 10.1126/ science. 1242121

Colautti, R. I., \& Lau, J. A. (2015). Contemporary evolution during invasion: Evidence for differentiation, natural selection, and local adaptation. Molecular Ecology, 24(9), 1999-2017. DOI: 10.1111/mec.13162

CVC. (1990). Comparación de cobertura de bosques y humedales entre 1957 y 1986 con delimitación de las comunidades naturales críticas en el valle geográfico del río Cauca. Cali, Colombia: Corporación Autónoma Regional del Valle del Cauca, CVC.

Diamond, S. E., Nichols, L. M., Pelini, S. L., Penick, C. A., Barber, G. W., Cahan, S. H., ... Gotelli, N. J. (2016). Climatic warming destabilizes forest ant communities. Science Advances, 2(10), e1600842. DOI: $10.1126 /$ sciadv. 1600842

Etter, A., \& van Wyngaarden, W. (2000). Patterns of Landscape Transformation in Colombia, with Emphasis in the Andean Region. AMBIO: A Journal of the Human Environment, 29(7), 432-439. DOI: 10.1579/0044-7447-29.7.432

Farkas, T. E., Mononen, T., Comeault, A. A., Hanski, I., \& Nosil, P. (2013). Evolution of camouflage drives rapid ecological change in an insect community. Current Biology, 23(19), 1835-1843. DOI: 10.1016/j. cub.2013.07.067

Fernández, F., Cartro-Huertas, V., \& Serna, F. (2015). Hormigas cortadoras de hojas de colombia: Acromyrmex \& Atta (Hymenoptera: Formicidae). Bogotá D.C.: Universidad Nacional de Colombia, Facultad de Ciencias, Instituto de Ciencias Naturales.
Fierst, J. L. (2011). A history of phenotypic plasticity accelerates adaptation to a new environment. Journal of Evolutionary Biology, 24(9), 1992-2001. DOI: 10.1111/j.1420-9101.2011.02333.x

Fjerdingstad, E. J., \& Boomsma, J. J. (1998). Multiple mating increases the sperm stores of Atta colombica leafcutter ant queens. Behavioral Ecology and Sociobiology, 42, 257-261.

Futuyma, D. J. (2001). Ecological specialization and generalization. In C. W. Fox \& D. A. Roff (Eds.), Evolutionary Ecology: Concepts and Case Studies: Concepts and Case Studies (pp. 177-189). Oxford: Oxford University Press.

GEMA. (1998). El Bosque seco Tropical (Bs-T) en Colombia. In Programa de inventario de la Biodiversidad (pp. 1-24). Retrieved from http://araneus.humboldt. org.co/download/inventarios/bst/Doc3.pdf

Ghalambor, C. K., McKay, J. K., Carroll, S. P., \& Reznick, D. N. (2007). Adaptive versus non-adaptive phenotypic plasticity and the potential for contemporary adaptation in new environments. Functional Ecology, 21(3), 394-407. DOI: 10.1111/j.1365-2435.2007.01283.x

Gimeno, T. E., Pas, B., Lemos-Filho, J. P., \& Valladares, F. (2009). Plasticity and stress tolerance override local adaptation in the responses of Mediterranean holm oak seedlings to drought and cold. Tree Physiology, 29(1), 87-98. DOI: 10.1093/treephys/tpn007

Grant, P. R., \& Grant, B. R. (2006). Evolution of Character Displacement in Darwin's Finches. Science, 313(5784), 224-226. DOI: 10.1126/science. 1128374

Heath, D. D., Heath, J. W., Bryden, C. A., Johnson, R. M., \& Fox, C. W. (2003). Rapid evolution of egg size in captive salmon. Science, 299(5613), 1738-1740. DOI: $10.1126 /$ science. 1079707

Hoffmann, A. A., \& Sgró, C. M. (2011). Climate change and evolutionary adaptation. Nature, 470(7335), 479485. DOI: $10.1038 /$ nature 09670

Holdridge, L., Grenke, W. C., Hatheway, W. H., Liang, T., \& Tosi, J. A. (1971). Forest environments in tropical life zones: a pilot study. Oxford: Pergamon Press. Retrieved from http://www.cabdirect.org/abstracts/19716605728.html

Houle, D. (1991). Genetic Covariance of Fitness Correlates: What Genetic Correlations are Made of and Why it Matters. Evolution, 45(3), 630. DOI: $10.2307 / 2409916$

James, A. C., \& Partridge, L. (1995). Thermal evolution of rate of larval development in Drosophila melanogaster in laboratory and field populations. Journal of Evolutionary Biology, 8(3), 315-330. DOI: 10.1046/j.1420-9101.1995.8030315.x 
Kawecki, T. J., \& Ebert, D. (2004). Conceptual issues in local adaptation. Ecology Letters, 7(12), 1225-1241. DOI: $10.1111 /$ j.1461-0248.2004.00684.x

Kinnison, M. T., Hendry, A. P., \& Stockwell, C. A. (2007), Contemporary evolution meets conservation biology II: impediments to integration and application. Ecological Research, 22(6), 947-954. DOI: 10.1007/ s11284-007-0416-6

Kisdi, E. (2002). Dispersal: risk spreading versus local adaptation. The American Naturalist, 159(6), 579596. DOI: $10.1086 / 339989$

Leal, I. R., Wirth, R., \& Tabarelli, M. (2014). The Multiple Impacts of Leaf-Cutting Ants and Their Novel Ecological Role in Human-Modified Neotropical Forests. Biotropica, 1-13. DOI: 10.1111/btp.12126

Lighton, J. R. B., Bartholomew, G. A., \& Feener Jr., A. D. H. (1986). Energetics of Locomotion and Load Carriage and a Model of the Energy Cost of Foraging in the Leaf-Cutting Ant Atta colombica Guer. Physiological Zoology, 60(5), 524-537.

Mayr, E. (1942). Systematics and the Origin of Species. New York: Columbia University Press. Retrieved from http://www.sidalc.net/cgi-bin/wxis. exe/?IsisScript $=$ UACHBC.xis\&method=post $\&$ forma to $=2 \&$ cantidad $=1 \&$ expresion $=\mathrm{mfn}=038503$

Meyer, S. T., Leal, I. R., \& Wirth, R. (2009). Persisting hyper-abundance of leaf-cutting ants (Atta spp.) at the edge of an old Atlantic forest fragment. Biotropica, 41, 711-716. DOI: 10.1111/j.1744-7429.2009.00531.x

Montoya-Lerma, J., Giraldo-Echeverri, C., Armbrecht, I., Farji-Brener, A. G., \& Calle, Z. (2012). Leafcutting ants revisited: Towards rational management and control. International Journal of Pest Management, 58(January 2015), 225-247. DOI: $10.1080 / 09670874.2012 .663946$

Moran, N. A. (1992). The Evolutionary Maintenance of Alternative Phenotypes. The American Naturalist, 139(5), 971-989.

Moser, J. C. (1967). Mating Activities of Atta texana (Hymenoptera, formicidae). Insectes Sociaux, 13(3), 295-312.

Mousseau, T. A., \& Fox, C. W. (1998). The adaptive significance of maternal effects. Trends in Ecology \& Evolution, 13(10), 403-407. Retrieved from http:/www.sciencedirect.com/science/article/pii/ S0169534798014724

Mousseau, T. A., Sinervo, B., \& Endler, J. A. (2000). Adaptive genetic variation in the wild. USA: Oxford University Press.

Nunes de Oliveira, S., Abílio de Carvalho, J., Trancoso Gomes, R. A., Fontes Guimarães, R., \& Concepta Margaret, M. (2017). Deforestation analysis in protected areas and scenario simulation for structural corridors in the agricultural frontier of Western Bahia, Brazil. Land Use Policy, 61, 40-52. DOI: 10.1016/j. landusepol.2016.10.046

Opdam, P., \& Wascher, D. (2004). Climate change meets habitat fragmentation: Linking landscape and biogeographical scale levels in research and conservation. Biological Conservation, 117, 285-297. DOI: 10.1016/j.biocon.2003.12.008

Phillips, B. L., \& Shine, R. (2006). An invasive species induces rapid adaptive change in a native predator: cane toads and black snakes in Australia. Proceedings of the Royal Society B, 273(1593), 1545-1550. DOI: $10.1098 / \mathrm{rspb} .2006 .3479$

Pigeon, G., Festa-Bianchet, M., Coltman, D. W., \& Pelletier, F. (2016). Intense selective hunting leads to artificial evolution in horn size. Evolutionary Applications, 9(4), 521-530. DOI: 10.1111/eva.12358

Pigliucci, M. (2001). Phenotypic Plasticity: Beyond Nature and Nurture. Baltimore, United States of America: The Johns Hopkins University Press.

Powell, R. J., \& Stradling, D. J. (1986). Factors influencing the growth of Attamyces bromatificus, a symbiont of attine ants. Transactions of the British Mycological Society, 87, 205-213.

Pulido, F., \& Berthold, P. (2004). Microevolutionary Response to Climatic Change. Advances in Ecological Research, 35(04), 151-183. DOI: 10.1016/ S0065-2504(04)35008-7

R Core Team. (2015). R: A Language and Environment for Statistical Computing. Vienna, Australia: R Foundation for Statistical Computing. Retrieved from http:// www.r-project.org

Ramírez, M., Chacon, P., Armbrecht, I., \& Calle, Z. (2002). Contribución al conocimiento de las interacciones entre plantas, hormigas y homópteros en bosques secos de Colombia. Caldasia, 23(2), 523-536. Retrieved from http://www.revistas.unal.edu.co/index.php/ cal/article/view/17721

Reznick, D. N., \& Ghalambor, C. K. (2001). The population ecology of contemporary adaptations: what empirical studies reveal about the conditions that promote adaptive evolution. Genetica, 112(1), 183-198.

Reznick, D. N., Shaw, F. H., Rodd, F. H., \& Shaw, R. G. (1997). Evaluation of the Rate of Evolution in Natural Populations of Guppies (Poecilia reticulata). Science, 275(5308), 1934-1937. DOI: 10.1126/ science. 275.5308 .1934

Richards, C. L., Bossdorf, O., Muth, N. Z., Gurevitch, J., \& Pigliucci, M. (2006). Jack of all trades, master of some? On the role of phenotypic plasticity in plant invasions. Ecology Letters, 9, 981-993. DOI: 10.1111/j.1461-0248.2006.00950.x 
Saverschek, N., Herz, H., Wagner, M., \& Roces, F. (2010). Avoiding plants unsuitable for the symbiotic fungus: learning and long-term memory in leaf-cutting ants. Animal Behaviour, 79, 689-698. DOI: 10.1016/j. anbehav.2009.12.021

Shik, J. Z., Santos, J. C., Seal, J. N., Kay, A., Mueller, U. G., \& Kaspari, M. (2014). Metabolism and the Rise of Fungus Cultivation by Ants. The American Naturalist, 184(3), 364-373. DOI: 10.1086/677296

Shirangi, T. R., Dufour, H. D., Williams, T. M., \& Carroll, S. B. (2009). Rapid evolution of sex pheromoneproducing enzyme expression in Drosophila. PLoS Biology, 7(8), e1000168. DOI: 10.1371/journal. pbio. 1000168

Singer,M.C.(2000). Reducing ambiguity in describing plantinsect interactions : "preference","acceptability" and "electivity." Ecology Letters, 3(3), 159-162. DOI: 10.1046/j.1461-0248.2000.00136.x

Slatkin, M. (1987). Gene Flow and the Geographic Structure of Natural Populations. Science, 236(4803), 787-792.

Snell-Rood, E. C. (2013). An overview of the evolutionary causes and consequences of behavioural plasticity. Animal Behaviour, 85(5), 1004-1011. DOI: 10.1016/j. anbehav.2012.12.031

Stockwell, C. A., Hendry, A. P., \& Kinnison, M. T. (2003). Contemporary evolution meets conservation biology. Trends in Ecology and Evolution, 18(2), 94-101. DOI: $10.1016 / \mathrm{s} 0169-5347(02) 00044-7$

Stockwell, C. A., \& Weeks, S. C. (1999). Translocations and rapid evolutionary responses in recently established populations of western mosquitofish (Gambusia affinis). Animal Conservation, 2(2), 103-110.
Szucs, M., Schaffner, U., Price, W. J., \& Schwarzländer, M. (2012). Post-introduction evolution in the biological control agent Longitarsus jacobaeae (Coleoptera: Chrysomelidae). Evolutionary Applications, 5(8), 858-868. DOI: 10.1111/j.1752-4571.2012.00264.x

Thiele, T., Kost, C., Roces, F., \& Wirth, R. (2014). Foraging Leaf-Cutting Ants Learn to Reject Vitis vinifera ssp. vinifera Plants that Emit Herbivore-Induced Volatiles. Journal of Chemical Ecology, 40(6), 617620. DOI: $10.1007 / \mathrm{s} 10886-014-0460-\mathrm{y}$

Tizón, R., Wulff, J., \& Peláez, D. (2014). The effect of increase in the temperature on the foraging of Acromyrmex lobicornis (Hymenoptera: Formicidae). Zoological Studies, 53(1), 40. DOI: 10.1186/ s40555-014-0040-4

Valladares, F., Sanchez-Gomez, D., \& Zavala, M. A. (2006). Quantitative estimation of phenotypic plasticity: Bridging the gap between the evolutionary concept and its ecological applications. Journal of Ecology, 94(6), 1103-1116. DOI: 10.1111/j.1365-2745.2006.01176.x

White, J. A. (2011). Caught in the act: Rapid, symbiontdriven evolution. BioEssays, 33(11), 823-829. DOI: 10.1002/bies.201100095

Wilson, C., Liang, B., Wilson, S., \& Akiwumi, F. (2018). Land Use, Microclimate, and Surface Runoff Linkages : Space-Time Modeling From Rokel-Seli River Basin, Sierra Leone. I International Archives of the Photogrammetry, Remote Sensing \& Spatial Information Sciences, 42(8), 29-31.

Wirth, R., Herz, H., Ryel, R. J., Beyschlag, W., \& Hölldobler, B. (2003). Herbivory of leaf-cutting ants. A case study on Atta colombica in the tropical rain forest of Panama. R. Wirth (Ed.). NewYork: Springer Verlag Berlin. 